\title{
Socially responsible landscape parks: A case study of landscape parks of Wielkopolskie voivodship
}

\author{
Magdalena Maćkowiak*, Aleksandra Spychała, Sylwia Graja-Zwolińska
}

Katedra Turystyki Wiejskiej, Uniwersytet Przyrodniczy w Poznaniu

ul. Witosa 45/20, 61-693 Poznań

* mackowiak_magda@wp.pl•ORCID 0000-0002-7514-0986

\begin{abstract}
Initially, research on 'social responsibility' focused on the sphere of business (corporate social responsibility, CSR). However, taking into account the fact that social responsibility is connected with understanding society's expectations in a broader perspective, the concept is now considered applicable to all organisations, not only business ones. The aim of this article is to draw attention to the problems in the socially responsible functioning of landscape parks. The areas of activity of parks, for which specific legal, ethical or economic expectations may be formulated by various groups of stakeholders, are characterised. The results of pilot surveys carried out among employees of landscape parks in the Wielkopolskie voivodship are also presented.
\end{abstract}

\section{Keywords}

CSR, social responsibility of the organisation, landscape park

\section{Introduction}

The definitions of responsible business are dominated by a purely economic approach to this issue, while CSR itself is referred to as a management strategy, or the concept of running a company. However, social responsibility does not apply only to business organizations. Elements of social responsibility are connected with the broadly understood expectations of the global society, the local community, as well as individuals. Therefore, the term social responsibility of the organization is increasingly used, because every organization (business, public, non-profit, small, medium, etc. according to the division criterion) should act socially responsible (Walkowiak 2009: 10).

The theoretical aim of this article is to present the issues of social responsibility of organizations in relation to the functioning of landscape parks, to indicate the areas of their activities in which it is possible to implement the assumptions of this idea and the ways of its implementation. The literature considerations were supplemented with the results of pilot studies carried out among the employees of landscape parks in the Wielkopolskie voivodship. 


\section{The essence of the social responsibility of the organization}

Social responsibility is considered as one of the greatest challenges of the $21^{\text {st }}$ century and plays an increasingly important role in the functioning of many enterprises. Organizations around the world and their stakeholders are increasingly aware of the need for socially responsible activities and their benefits. The attitude of the organization towards the society in which it functions and its impact on the environment is becoming an essential element in assessing the performance of the organization as a whole and its ability to continue to act effectively (Krodkiewska-Skoczylas, Żarlicka 2015: 277).

In the literature on the subject, the concept of corporate social responsibility is defined, among others, as the degree to which a company undertakes economic, legal, ethical and discretionary obligations imposed on it by parties involved in its activities (Maignan et al. 1999: 457) or expectations of the aforementioned type that society has towards the organization at a given moment (Carroll 1979: 499).

Based on these definitions, it can be stated that the social responsibility of the broadly understood organization can be treated in a multidimensional manner and manifested in diverse activities (Web-01). A socially responsible organization should be aware of its impact on society and the environment. The decisions and actions affecting the environment should be transparent and based on ethics, fairness, equality and integrity. Organizational responsibility also manifests itself in respect for the needs and expectations of stakeholders, as well as the acceptance and respect of applicable law. It is also extremely important to respect human rights and to consider both their importance and universality (Projekt standardu... 2009)

The multitude of planes that can be affected by socially responsible activities does not mean that organizations wishing to act according to this concept must demonstrate responsibility at all levels simultaneously (Wołoszyn, Ratajczak 2012: 9). The investigation into the full implementation of the assumptions of this idea is a process spread over time.

The social responsibility of an organization can be considered in three dimensions:

- internal - directed to internal interest groups in organization, i.e. owners, managerial staff, other employee groups, trade unions;

- external - addressed to stakeholders operating in a closer and further environment, i.e. clients, suppliers, competitors, financial institutions, representatives of state and local administration, business organizations, local communities, social organizations, media, international institutions;

- activities related to the natural environment - taking into account the environmental aspect of the company's activities, including the impact of the entity on its condition, caring for the natural environment (Żelazna-Blicharz 2013: 14).

It is also extremely important that socially responsible activities are undertaken by the organization's owners on a voluntary basis (Rok 2004: 70) and should be implemented mainly to improve relations with stakeholders (Kalinowska 2012: 330).

In the context of the theoretical considerations quoted above, the question was posed: can one talk about the social responsibility of landscape parks and, if so, in what areas can it be implemented?

\section{Plane social responsibility of landscape parks}

Landscape parks as organizations are entrusted with general public goods, which are natural and cultural values, whose protection becomes their statutory task. The purpose of parks is also to conduct educational activities and create conditions for the development of forms of tourism desired in the protected area. 
A characteristic feature of this form of nature protection is also the possibility of economic use of the area covered by it, which is particularly important due to the fact that landscape parks are often areas of great potential. This potential should be used in a manner consistent with the principles of sustainable development and with respect for protective provisions.

It is the multiplicity of functions assigned to landscape parks that makes the group of their stakeholders i.e. entities (people, communities, institutions, organizations, offices), which may influence the organization or remain influenced by its activities (Freeman 1994: 417). In the case of parks, these include the Minister of Environment, regional council, municipalities, Regional Directorate for Environmental Protection, park employees, residents, tourists, students, National Fund for Environmental Protection and Water Management and voivodeship funds for environmental protection and water management. Indication of stakeholders in the case of a landscape park is important because their actions often determine the possibility of effective implementation of protective tasks (Donaldson, Preston 1995: 66).
Management of protected areas should be based primarily on cooperation between various groups of entities, including central government, local authorities, private companies, NGOs and residents (Stockdale, Barker 2009; Lockwood 2010) (Fig. 1).

So how should landscape parks work in order to fulfill socially responsible tasks assigned to them? The areas of social responsibility in the landscape parks activity can have a diverse character. They may include organizational aspects, task planning, actions in the field of protection of securities, supervision of respecting the introduced prohibitions, broadly understood cooperation and financial management.

Presented areas of socially responsible activities in landscape parks have been proposed based on, among others on the report of the Supreme Audit Office Implementation of statutory tasks in landscape parks. Information on the results of the inspection (Web-02). Determining the scope of social responsibility of parks can be treated as an attempt to define the conditions that must be met so that these institutions effectively protect the natural and cultural environment in the event of leaving in the economic use of the land

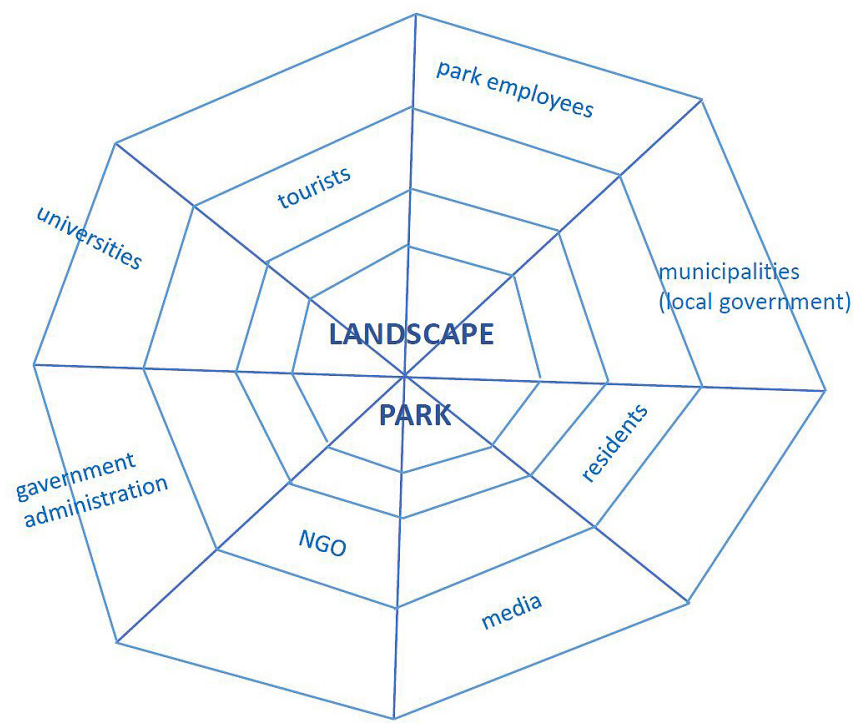

Fig. 1. Example stakeholders of a landscape park. Source: own study 
subjected to protection, when the living and managing communities want to develop and improve (Web-o3).

\section{Socially responsible activities in landscape parks}

Problems regarding the functioning of landscape parks began in the 1990 os and have been described in more detail in several monographs (Kurowski, Witosławski 2002; Zimniewicz 2002; Mizgajski 2003; Kistowski 2004).

Landscape park so that it can effectively and socially responsible carry out the tasks entrusted to it, should be a well organized and well managed institution (Kistowski 2012). It is, among others, about the existence of a legal framework for the functioning of the park, delineation of its boundaries, proper organizational structure and staffing situation. Each park should have its own, well-marked headquarter, preferably in the park itself, so that employees can always be present on its premises and that all interested parties can always get direct contact. In the socially responsible functioning of a landscape park, it is extremely important to employ well and properly educated employees. It is also important to provide them with opportunities to improve the skills needed to perform work, that is participation in training, conferences in the field of nature and landscape protection, conducting negotiations, changes in regulations, their use, etc. It is also important to properly equip the work places, work organization, the nature of the tasks performed, participation and delegation of powers.

Another aspect of park activities, where social responsibility assumptions should be taken into account, is task planning. A landscaped park should have clearly defined goals and methods of action, which entails defining clear priorities and ways to protect values (which depends largely on existing legal regulations). The park should also have a well-developed and systematically implemented protection plan.
Due to its lack, parks do not have the basic instrument for planning protective tasks in a given area in the long-term perspective.

A manifestation of the responsibility of parks for the common goods entrusted to them is proper supervision over respecting the prohibitions introduced in the parks. For this purpose, it is necessary to conduct systematic monitoring activities, such as patrols or field inspections, and in the case of irregularities - notification of the competent authorities of the commune, building supervision, municipal police, fire brigade or police to establish and punish the guilty and take corrective action.

A landscaped park should also actively seek partners for cooperation and strive for establishing permanent contacts with administrative authorities, first of all with municipalities. Convincing local governments for the necessity of joint action is one of the basic conditions for effective protection of values. Co-operation may take the form of mutual non-binding consultations, informing and notifying about planned activities, presenting their position on the case, arrangements for directions of activities, etc. In situations, where the scope of cooperation is not regulated by law, it should be a part of a good practice and partnership.

A landscaped park should have adequate financial potential, enabling the implementation of protective tasks. It should have priority access to voivodship means of financing environmental protection - voivodship funds for environmental protection and water management should primarily support pro-ecological activities implemented in protected areas (including landscape parks). The establishment of the park should also involve providing funds to protect its values, especially in the initial phase of its functioning. The park should also be able to provide at least partial financial compensation to private owners in cases of losses caused by changing the way of management for environmentally friendly or directly affecting the protection of values (e.g. change of the heating method or organic farming). 
In opposition to socially responsible activities, one can also point out many practices that affect the reduction of the effectiveness of protective activities in landscape parks and their surroundings (Maćkowiak 2016: 57).

In the organizational sphere:

- functioning of the park, which is a cohesive area in terms of natural values, within separate organizational structures, entailing, inter alia, the need to develop separate planning documents;

- formal difficulties regarding the transfer of part of the subsidy allocated to the functioning of landscape parks between neighbouring voivodships, constituting justification for the operation of parks of the same name in separate organizational structures;

- entrusting to the heads of teams of landscape parks tasks related to other forms of nature protection, located also outside the landscape parks;

- minimizing the advisory and evaluation functions of the parks' councils and landscape parks' assemblies, which limits the participation of social factors in decision-making, and also the requirement to sit on these councils of representatives with a high level of expertise that may affect the quality of these decisions;

- lack of adequate housing base, in particular of the education base, and insufficient number or lack of appropriate cars.

In the sphere of planning:

- unjustified postponement during the preparation of the protection plan;

- continuation of work on the establishment of conservation plans, despite the lack of establishing protective tasks for the Natura 2000 site located in the landscape park.

In the sphere of activities in the field of values protection:

- lack of the possibility to effectively enforce the provisions of landscape parks protection plans in practice in relation to the decision on building conditions;

- $\quad$ limiting the possibility of implementing statutory tasks in parks as a result of taking over by the Regional Directorates of Environmental Protection some employees of Landscape Service Units (SPK), while reducing financial resources for employment and preserving tasks of landscape parks under the Nature Conservation Act (A) and qualification requirements SPK8;

- a short date for reconciliation of investments planned for implementation in landscape parks is indicated as the reason for the lack of such a reconciliation.

The sphere of supervision over respect of existing prohibitions:

- insufficient human resources and insufficient technical potential, resulting in incomplete implementation of the statutory tasks of the SPK in the field of environmental inventory, identification and assessment of existing and potential threats to monitor compliance with prohibitions in force in the park;

- lack of systematic activities carried out in the field, supervision of respecting the bans through analysis and giving opinions on submitted planning documents and decisions;

- discrepancies in decisions taken at various levels, e.g. regarding the reconciliation of building conditions questioning the provisions of the first instance authority by a higher one.

In the sphere of cooperation:

- lack of cooperation between landscape park directors and the regional directorate for environmental protection, especially regarding the reconciliation of the conditions for building planned investments;

- adding to the municipal or city council the reconciliation of a draft resolution regarding, for example, the 
extension of a park area located on its territory, from the relaxation or abolition of most of the bans in force;

- failure to inform the directors of parks or landscape parks' teams by competent public administration authorities about administrative proceedings being initiated regarding investments planned for implementation in landscape parks.

In the area of financial management, illegal activities may occur when contracts are concluded or settled and expenditure is realized. They can depend on:

- non-compliance with the provisions of the concluded contracts,

- concluding contracts for an indefinite period with contractors selected on the basis of the provisions of the Public Procurement Law,

- unsecured parks' interests in concluded contracts,

- accepting works and paying remuneration to contractors, even though the works performed did not meet the requirements specified in the agreements.

\section{Landscape parks of the Wielkopolskie voivodship}

There are 13 landscape parks on the analyzed area (Fig. 2), which together cover almost 180, ooo hectars, which is slightly above $6 \%$ of the province's surface area (Rocznik statystyczny 2017). Three such areas are of cross-border nature: Pszczewski, Przemęcki and Barycz Valley. The first protected areas of this type in Wielkopolska were created at the end of the 198 os (Lednicki and Pszczewski), but the most were founded in the 1990s. The youngest landscape park is the Nadgoplański Park Tysiąclecia (Skulsk commune), established in 2009 . The Promno Landscape Park is the smallest protected area of this type (3,0oo hectars) (Web-04). Within the voivodship there is a fragment (only $20.23 \%$ of the total area) of the largest landscape park in Poland Barycz Valley.

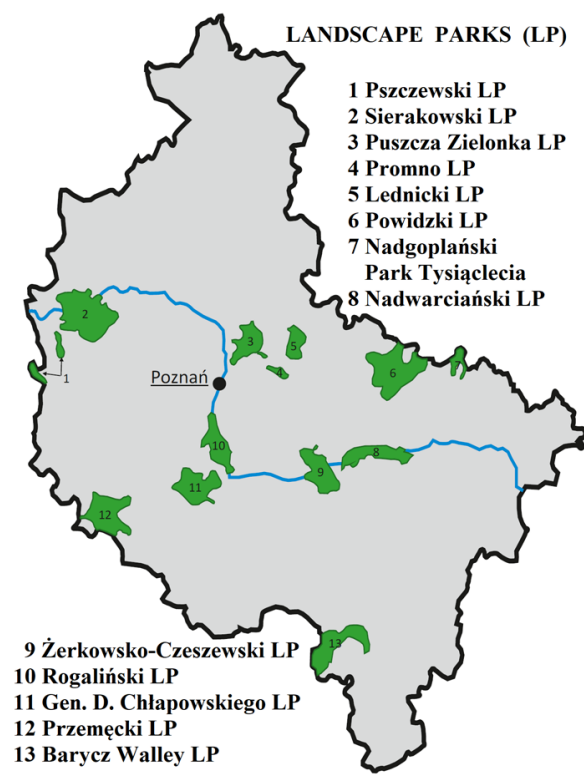

Fig. 2. Landscape parks of the Wielkopolskie voivodship

Source: https://pl.wikipedia.org/wiki/

Zesp\%C3\%B3\%C5\%82_Park\%C3\%B3w_Krajobrazowych_

Wojew\%C3\%B3dztwa_Wielkopolskiego (9/02/2019)

Such protected areas of Wielkopolska are characterized by a diversified landscape, which is a consequence of the Scandinavian glacier. Hence the occurrence of bottom and frontal moraine, post-glacial gutters or sander plains. Concentration of these forms translates into the presence of many attractive vantage points, and on the other hand, it creates huge potential for the development of various forms of tourism and recreation. Landscape parks in the Wielkopolskie voivodship are also famous for well-known cultural values such as Ostrów Lednicki with the remnants of Mieszko I and Bolesław the Brave, BaroqueClassicist Raczyński's palace in Rogalin or a hunting palace in Antonin.

Numerous walking, cycling, horseriding, water trails and didactic routes run through the Wielkopolska landscape parks - according to the recent analyzes, there are about 50. A wide range of ecological education classes is carried out in two centers located in Chalin and Ląd. 
Less than 26 full-time employees take care of the implementation of statutory actions, and the substantive support in the field of the implementation of the protective function is provided by the Council of Landscape Parks of the Wielkopolska Voivodship.

The dissemination of natural and cultural values are served by various actions implemented by various entities and institutions, including by the Board of Wielkopolska Landscape Parks - cyclic walks accompanied by a guide for each park: "Go astray", walking and cycling rallies, rafting, photography, recitation, art contests, knowledge about parks, etc. Two mobile applications were also prepared for the youngest visitors ("Bee" and "Antonin Path") and outdoor games - quests (11) (Web-05).

As noted, among others Spychała (2010: 160) the mere coverage of the area with the status of a landscape park generates tourism, but it should develop as part of forms of cultural and natural tourism (Uglis et al. 2012: 31).

\section{Methodology of empirical research}

The presented results are the result of pilot studies carried out among employees of landscape parks located within the Wielkopolskie voivodship. The assumed intelligence questionnaire will be directed to employees of all landscape parks in Poland.

It should be emphasized that the work on the questionnaire included consultations with representatives of the administration of various protected areas as well as with the management of the Landscape Parks Complex of the Wielkopolska Voivodship (Zespół Parków Krajobrazowych Województwa Wielkopolskiego). Discussion and mutual exchange of views as well as the confrontation of theoretical and practical assumptions were to serve the proper formulation of questions and their interpretation.

Finally, the questionnaire consisted of 28 closed questions with a 7-element Likert scale. The introduction of such a version of the Likert scale was aimed at increasing the accuracy of the measurement. Its popularity is determined by the relative simplicity of scale construction, standard principles of checking one-dimensionality and reliability, the ability to capture many aspects of the phenomenon studied, and the convenience of using the form of a synthetic variable (Jezior 2013: 118). On the other hand, the issues included in the research questions form the thematic blocks in the questionnaire, which group questions from a given scope (Olbrych 2009: 138).

The issues included in the questionnaire were divided into the following blocks:

- organization of work in the aspect of the possibility of realizing the assumptions of social responsibility;

- $\quad$ substantive and legal tools (scientific council, current protection plans, etc.) and implementation of the ecological function;

- the attitude of administration to the local environment.

The research was carried out from September to November 2018. Despite the complexity of works on the preparation of the questionnaire itself, the effectiveness of research in the first stage implemented among representatives of landscape parks in Wielkopolska proved to be low. Only 11 completed surveys were received.

The authors of the research, striving to diagnose the cause of the distance or sometimes even the reluctance of the respondents to express their opinion, submitted the results of the independent expert consultation (among the representatives of protected areas). The effect of these meetings was a jointly developed intelligence questionnaire.

\section{Research results}

It should be emphasized that respondents always had the same range of answers to choose from: yes, rather yes, hard to say, rather not, no. For this reason, these options were often grouped as positive (positive two), negative (last two) and neutral opinions. In a few cases, the issues that were examined 
were still divided into individual main functions, which the landscape park was supposed to play in the legislator (didactic, ecological, protective), but the conclusions were made jointly.

The survey questionnaire begins with questions about the employees themselves, in the opinion of the respondents in the team there are far too few employees over half of them answered this question; on the other hand there is a large number of ambiguous indications (3) and one definitely contradictory.

It is not surprising that the answer to the next issue that raises the relevant competences of employees - the respondents judge themselves positively as properly prepared in terms of content.

When it comes to the possibility of professional development, in general, six people do not see such opportunities, but at the same time three people are convinced that they exist, two people have no responsibility in this matter.

The study also asked about the motivation system, possibly encouraging a stronger involvement in professional activities - in this case, as many as nine respondents had negative opinions, and two people could not take an unequivocal position. Almost identical distribution of responses was obtained by discussing the subject of an efficient and satisfying system of communication between employees.

Employees rated their creativity very high - up to nine respondents believe that it is the person who contributes to the tasks performed by landscape parks.

The next part of the questionnaire concerned the organizational structure of Landscape Parks Complex of the Wielkopolska Voivodship (LPCWV) - Fig. 3 illustrates the answers of respondents regarding its impact on the implementation of specific functions assigned to this form of nature protection. Positive opinions prevail in a slightly different configuration, while the majority of affirmative indications received didactic tasks.
Respondents were asked for a statement about the LPCWV Council. Four respondents welcomed its substantive competences, however, the majority (six) did not take a position on this issue. Lack of willingness to answer - or maybe a solid knowledge of the topic - on this issue also confirm questions regarding the possible use of knowledge of board members in the implementation of specific functions; the distribution of opinions was identical: up to ten employees had no opinion on the matter.

The least problematic issues were questions about external sources of financing the implementation of projects, as well as promotion of activities aimed at protecting the natural environment (e.g. segregation of rubbish). All employees are convinced that LPCWV is active both in the sphere of projects and in the promotion of pro-ecological behaviour.

A very important document, properly necessary for the proper operation of a landscape park, is its protection plan; however, as previously stated, not all parks included in the LPCWV have such a study. As for its impact on the implementation of the protective function, the majority of the respondents (eight) confirmed the positive role of the document (Fig. 4). However, in the case of didactic and ecological functions, half of the respondents could not give a definite answer - perhaps this is due to the fact that up to nine respondents defined their professional tasks as related to protection. Also, the protection relates primarily to bans that compliance should be supervised by the employees of that unit - is this really the case? Eight respondents confirm this thesis, but on the other hand two employees rather reject it.

Another analysed issue concerns possible cooperation with municipalities, to which the landscape park belongs administratively. In this case, the respondents are very much in agreement - most of them confirm such activities, especially in the didactic sphere (Fig. 5). Interestingly - according to employees, this cooperation takes into 


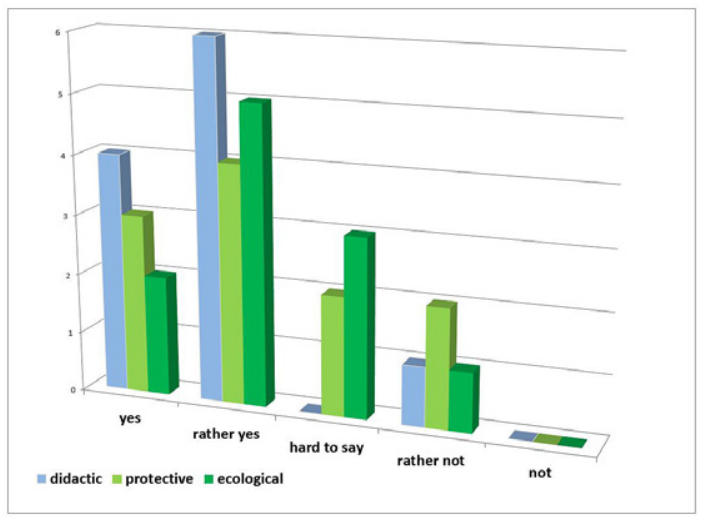

Fig. 3. The impact of organizational structure of Landscape Parks Complex of the Wielkopolska Voivodship on the implementation of specific functions assigned to landscape park.

Source: own study

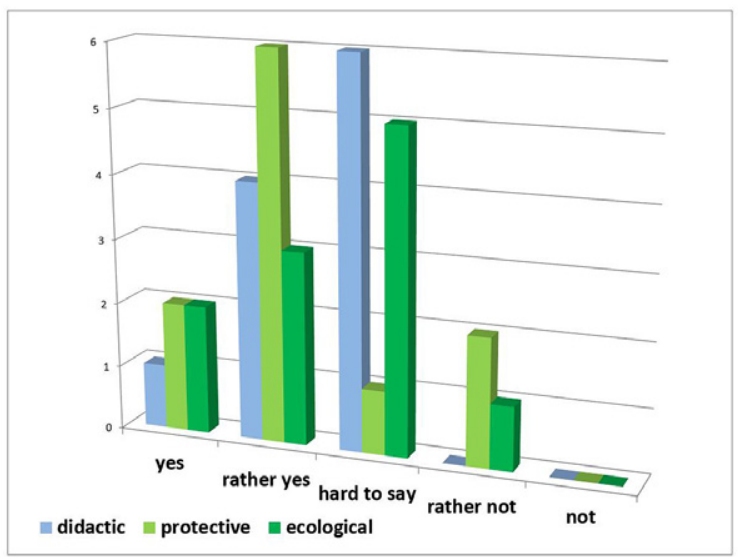

Fig. 4. The impact of protection plan on the implementation of specific functions assigned to landscape parks. Source: own study

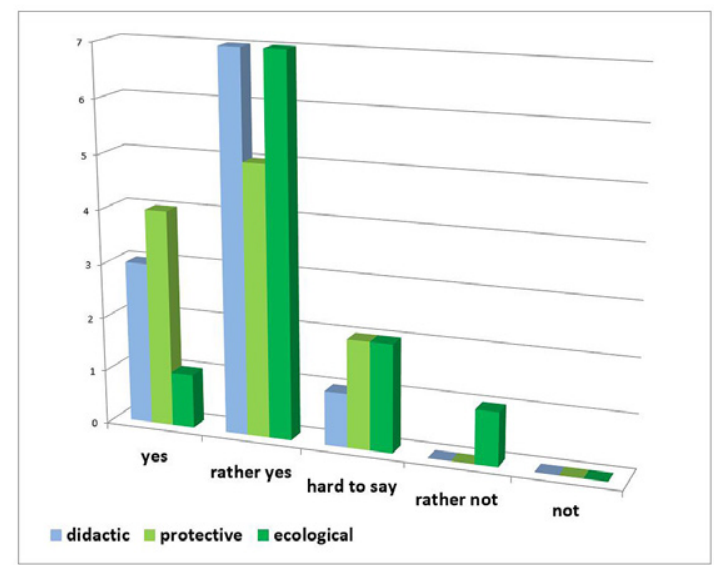

Fig. 5. The impact of cooperation with municipalities on the implementation of specific functions assigned to landscape parks. Source: own study 
account the needs of local communities! Thus, either the LPCWV conducted targeted research in this regard, or the respondents come from these territorial units and are perfectly aware of local expectations. Actually, it is uncertain, that any if these two version are really true, what confirms the necessity of conducting more detailed study concerning described subject.

The issue of joint activities in the economic field was discussed separately - and here there was a certain dissonance. Well, the distribution of responses regarding cooperation with local business was almost perfectly proportional (positive, negative and abstaining), although it should be emphasized that there was not a definitely positive option - the respondents only indicated the "rather yes" option. In turn, the statement "LPCWV supports the economic development of the region" was supported by six respondents, while five of them did not have an opinion in this regard. In other words, landscape parks as an institution support the local economy, but rather do not engage in private initiatives.

\section{Summary}

Considering the social responsibility of a non-profit organization, which are landscape parks, attention should be paid first of all to the fact whether it implements its objectives and tasks in an ethical manner, consistent with the law and taking into account the expectations set by its stakeholders. The main objective is not to improve financial performance, but rather a friendly attitude of society, building a competitive advantage as a settlement area and an attractive tourist area, or employees satisfaction, which translates into the way of performing duties.

The analyses made as well as the conclusions from the conducted research also show defects in the sphere of top-down organizational structure, which does not fully enable the implementation of key assumptions of social responsibility. Limitations resulting from, among others, the insufficient number of employees assigned to certain tasks, combined with the inflexible remuneration system, do not stimulate such activities, especially among younger people.

\section{Bibliography}

Borrini-Feyerabend G., Kothari A., Oviedo G., 2004, Indigenous and local communities and protected areas towards equity and enhanced conservation. Guidance on policy and practice for Co-managed protected areas and community conserved areas, World Commission on Protected Areas (WCPA), Best Practice Protected Area Guidelines Series No. 11, IUCN, Gland, Switzerland and Cambridge, UK. Carroll A.B., 1979, A three-dimensional conceptual model of corporate performance. Academy of Management Review, 4, 4, 497-505.

Donaldson T., Preston L.E., 1995, The stakeholder theory of the corporation: concepts, evidence, and implications, The Academy of Management Review, 20, 1, 65-91.

Ervin J., Sekhran N., Dinu A., Gidda S., Vergeichik M., Mee J., 2010, Protected Areas for the 21st Century: Lessons from UNDP/GEF's Portfolio, New York, United Nations Development Programme and Montreal: Convention on Biological Diversity.

Freeman R.E., 1994, The Politics of Stakeholder Theory, Business Ethics Quarterly, 4, 4, 409-421.

Jezior J., 2013, Metodologiczne problemy zastosowania skali Likerta w badaniach postaw wobec bezrobocia, Przegląd Socjologiczny, 62, 1, 117-132.

Kistowski M., 2004, Wybrane aspekty zarządzania ochroną przyrody w parkach krajobrazowych, Bogucki Wydawnictwo Naukowe, Gdańsk-Poznań.

Kistowski M., 2012, Problemy zarzadzania parkami krajobrazowymi w Polsce jako skutek zmian przepisów prawnych w latach 2008-2010, Problemy Ekologii Krajobrazu, t. 33, 215-227.

Kurowski K., Witosławski P. (red.), 2002, Funkcjonowanie parków krajobrazowych w Polsce. Wydawnictwo Uniwersytetu Łódzkiego, Łódź.

Kalinowska A., 2012, Wartość dla pracowników w koncepcji CSR, Zeszyty Naukowe Uniwersytetu Szczecińskiego nr 736, Finanse, Rynki Finansowe, Ubezpieczenia nr 55, 327-344.

Krodkiewska-Skoczylas E., Żarlicka G., 2015, Spoteczna odpowiedzialność nie tylko biznesu, w: Zrównoważony rozwój organizacji - aspekty społeczne, Prace Naukowe Uniwersytetu Ekonomicznego we Wrocławiu nr 738, Wydawnictwo 
Uniwersytetu Ekonomicznego we Wrocławiu, Wrocław, 277-295.

Lockwood M., 2010, Good Governance for Terrestrial Protected Areas: A Framework, Principles and Performance Outcomes, Journal of Environmental Management, 91, 754-766.

Maćkowiak M., 2016, Parki krajobrazowe a idea CSR, Przegląd Komunalny, 2, 56-57.

Maignan I., Ferrell O.C., Hult G.T.M., 1999, Corporate Citizenship: Cultural Antecedents and Business Benefits, Journal of the Academy of Marketing Science, 27, 455-469.

Mizgajski A., 2003, Finansowanie ochrony przyrody. Doświadczenia i perspektywy, Bogucki Wydawnictwo Naukowe, Poznań.

Olbrych B., 2009, Organizacja wywiadu z kwestionariuszem ankietowym do badania jakości ustug, Acta Universitatis Lodziensis Folia Oeconomica, 227, 137-149.

Rocznik statystyczny GUS, 2017, Ochrona środowiska. Phillips A., 2002, Management. Guidelines for IUCN Category V Protected Areas: Protected Landscapes/ Seascapes. Best Practice Protected Area Guidelines Series. IUCN, Gland, Switzer land and Cambridge, UK.

Phillips A., 2003, Turning Ideas on Their Head: The New Paradigm for Protected Areas, George Wright Forum, 20, 2, 8-32.

Projekt standardu ISO/DIS 260oo, 2009, Międzynarodowa Organizacja Normalizacyjna. Genewa.

Rok B., 2004, Odpowiedzialny biznes w nieodpowiedzialnym świecie, Akademia Rozwoju Filantropii w Polsce - Forum Odpowiedzialnego Biznesu, Warszawa.

Stockdale A., Barker A., 2009, Sustainability and the Multifunctional Landscape: An Assessment of Approaches to Planning and Management, Cairngorms National Park Land Use Policy, 26, 479-492. Spychała A., 2010, Funkcja turystyczna Parku Krajobrazowego „Dolina Baryczy”, Bogucki Wydawnictwo Naukowe, Poznań.

Uglis J., Jęczmyk A., Spychała A., 2012, Zasoby kulturowe rejonu wielkopolskich parków krajobrazowych, Turystyka Kulturowa, 9, 5-34.

Walkowiak R., 2009, Społeczna odpowiedzialność organizacji, w: Walkowiak R., Krukowski K. (red.), Społeczna odpowiedzialność organizacji - od odpowiedzialności do elastycznych form pracy, Fundacja
„Wspieranie i Promocja Przedsiębiorczości na Warmii i Mazurach", Olsztyn, 10-28.

Wołoszyn J., Ratajczak M., 2012, Modele społecznej odpowiedzialności biznesu - rozważania teoretyczne, w: J. Wołoszyn (red.), Społeczna odpowiedzialność biznesu w obszarze przedsiębiorczości, Wydawnictwo SGGW, Warszawa, 7-16.

Zimniewicz K. (red.), 2002, Zarzadzania parkiem krajobrazowym $w$ warunkach zrównoważonego rozwoju, Wydawnictwo Akademii Ekonomicznej, Poznań.

Żelazna-Blicharz A., 2013, Spoteczna odpowiedzialność w procesie gospodarowania a zrównoważona produkcja i konsumpcja, Politechnika Lubelska, Lublin.

Ustawa z 16 kwietnia 2004 r. o ochronie przyrody (DzU z 2015 r. poz. 1651, z późn. zm.).

Rozporządzenie Ministra Środowiska z 2 marca 2005 r. w sprawie stanowisk oraz wymagań kwalifikacyjnych, jakie powinny spełniać pracownicy zatrudnieni na poszczególnych stanowiskach w Służbach Parków Krajobrazowych (DzU z 2005 r. nr 41, poz. 395).

Ustawa z 29 stycznia 2015 r. Prawo zamówień publicznych (DzU z 2015 r. poz. 2164).

(Web-o1) Norma Międzynarodowa dotycząca społecznej odpowiedzialności https://www.pkn.pl/ informacje/2013/og/iso-26ooo, dostęp: 14.01.2019.

(Web-02) Realizacja ustawowych zadań w parkach krajobrazowych. Informacja o wynikach kontroli, KSI-4101-0100/2011, nr ewid. 120/2012/P11111/ KSI, www.nik.gov.pl/kontrole/P/11/111, dostęp: 14.01.2019.

(Web-o3) Jermaczek D.: Ochrona walorów parków krajobrazowych - pobożne życzenie czy realna rzeczywistość? Biuletyn Lubuskiego Klubu Przyrodników 3/20oo, http://www.eko.org.pl/lkp/ bociek/200o_3/20oo_3_parki_kraj.htm, dostęp: 14.01.2019.

(Web-04) http://www.zpkww.pl/parki/informacje-ogolne/informacje-ogolne, dostęp: 9.02.2019).

(Web-05) http://www.zpkww.pl/turystyka/gry-aplikacje/questy, dostęp: 9.02.2019. 
Parki krajobrazowe społecznie odpowiedzialne.

Studium przypadku parków krajobrazowych województwa wielkopolskiego

\section{Streszczenie}

Pierwotnie zainteresowania badawcze "odpowiedzialnością społeczną" koncentrowały się na sferze biznesu (CSR). Biorąc jednak pod uwagę fakt, że społeczna odpowiedzialność wiąże się ze zrozumieniem oczekiwań społeczeństwa w szerszej perspektywie, obecnie pojęcie to znajduje zastosowanie w odniesieniu do wszystkich organizacji, nie tylko biznesowych.

Celem artykułu jest zwrócenie uwagi na problematykę społecznie odpowiedzialnego funkcjonowania parków krajobrazowych.

Scharakteryzowano płaszczyzny działalności parków, wobec których mogą istnieć szczególne oczekiwania natury prawnej, etycznej czy ekonomicznej formułowane przez różne grupy interesariuszy. Przedstawiono także wyniki pilotażowych badań ankietowych zrealizowanych wśród pracowników parków krajobrazowych województwa wielkopolskiego.

\section{Stowa kluczowe}

CSR, odpowiedzialność społeczna organizacji, park krajobrazowy 